\title{
Arbuscular Mycorrhizal Fungal Communities in Organic and Conventional Onion Crops in the Columbia Basin of the Pacific Northwest United States
}

\author{
Anne Jean'ne Knerr, ${ }^{1}$ David Wheeler, ${ }^{2}$ Dan Schlatter, ${ }^{3}$ Dipak Sharma-Poudyal, ${ }^{4}$ Lindsey J. du Toit, ${ }^{5}$ and \\ Timothy C. Paulitz ${ }^{3,+}$ \\ ${ }^{1}$ Department of Plant Sciences, University of Idaho, Moscow; ${ }^{2}$ Department of Plant Pathology, Washington State \\ University, Pullman; ${ }^{3}$ U.S. Department of Agriculture-Agriculture Research Service, Wheat Health, Genetics, and \\ Quality Research Unit, Pullman, WA; ${ }^{4}$ Oregon Department of Agriculture, Salem, OR; and ${ }^{5}$ Department of Plant \\ Pathology, Washington State University-Mount Vernon NWREC, Mount Vernon
}

Accepted for publication 20 August 2018.

\section{ABSTRACT}

Onions are highly responsive to arbuscular mycorrhizal fungi (AMF), but little is known about AMF communities in onion crops $(\sim 10,000 \mathrm{ha})$ in the semiarid, irrigated region of the Columbia Basin of Washington and Oregon. AMF communities and root colonization were compared in organic and conventional onion fields, and between paired conventional fields that were fumigated or not with metam sodium. AMF were detected in all fields at all sampling times, with no differences in root colonization of onions used to bait soil from organic versus conventional and fumigated versus nonfumigated fields. However, AMF colonization of roots of onion plants sampled midsummer was greater in organic versus conventional fields (67 versus $51 \%$ ) and less in fumigated versus nonfumigated conventional fields (45 versus 67\%). Pyrosequencing identified four AMF genera (Glomus, Claroideoglomus, Paraglomus, and Diversispora) and four dominant operational taxonomic units
(OTUs) (Glomus mosseae (Funneliformis mosseae), Glomus Whitfield type 17, Claroideoglomus lamellosum, and Glomus MO_G17). AMF community structure in roots of onion plants collected from crops midsummer was different in organic versus conventional crops, with greater AMF diversity and richness in organic than conventional crops. There was no effect of organic versus conventional crops on dominant OTUs, but several lowabundance OTUs in organic fields were not detected in conventional fields. There was no consistent effect of metam sodium chemigation on AMF communities in onion crops. Overall, cropping practices in organic versus conventional onion production, and the use of metam sodium soil fumigation by center-pivot chemigation do not appear to be major drivers of AMF communities.

Additional keywords: Allium cepa.
Most land plants form associations with arbuscular mycorrhizal fungi (AMF) in the Phylum Glomeromycota (Smith and Smith 2011). These symbiotic fungi form arbuscules in root cells through

${ }^{\dagger}$ Corresponding author: Timothy Paulitz; E-mail: timothy.paulitz@ars.usda.gov

Funding: Funding for this project was received from the Pacific Northwest Vegetable Association, the Center for Sustaining Agriculture and Natural Resource Sciences BIOAg program at Washington State University, the Washington State Department of Agriculture Specialty Crop Block Grant K1769, and PPNS 0756 Department of Plant Pathology, College of Agricultural, Human, and Natural Resource Sciences, Agricultural Research Center, Hatch Project WPN00595, Washington State University, Pullman, 99164-6430, USA. D. C. Schlatter was funded by an administrator-funded USDA-ARS Postdoctoral Research Associate Award.

This article is in the public domain and not copyrightable. It may be freely reprinted with customary crediting of the source. The American Phytopathological Society, 2018 which fixed carbon is taken up by the fungus (Helgason and Fitter 2005). In turn, the fungus provides the plant with phosphorus (P) and other minor elements that are immobile or of limited availability to plants. Phosphorus is relatively immobile in the soil because the element forms insoluble complexes with abundant cations such iron (Fe), aluminum (Al), and calcium (Ca) (Weil and Brady 2017). Because of slow diffusion of $\mathrm{P}$ in the soil, a zone of depletion develops rapidly around plant roots. The AMF form an extensive hyphal network that substantially increases the surface area to absorb and transport $P$ into the roots (Smith and Smith 2011). AMF provide many other benefits, including protection against some plant pathogens and improved soil structure through soil aggregate formation from glomalin and hyphal networks that bind soil particles together (Finlay 2004).

Most studies on AMF diversity have focused primarily on natural ecosystems, revealing 10 to 20 AMF taxa per sample, with roots of 
individual plants capable of being infected by multiple AMF species (Baoming et al. 2013; Daniell et al. 2001; Jansa et al. 2003; Rosendahl and Stukenbrock 2004). Surprisingly, a greater degree of AMF diversity has been found within some agricultural ecosystems than previously hypothesized (Daniell et al. 2001; Hijri et al. 2006). With the development of next-generation sequencing methods such as pyrosequencing, a greater depth of sequencing can be obtained. However, there is controversy about whether operational taxonomic units (OTUs) identified using next-generation sequencing represent separate species or whether these methods overestimate AMF richness and diversity (Dumbrell et al. 2010; Gorzelak et al. 2012; House et al. 2016). Part of the difficulty is that these fungi are coenocytic and multinucleate, and the large AMF spores (up to $1,000 \mu \mathrm{m}$ in diameter) can contain thousands of nuclei, each of which may have a different population of ribosomal genes. There are also multiple copies of the genes within a given nucleus, making accurate estimation of the link between OTUs and species more difficult. Nevertheless, next-generation sequencing provides a powerful tool for examining questions of AMF community structure and diversity within agricultural ecosystems.

In agricultural systems, unlike native systems, plant nutrients such as nitrogen $(\mathrm{N})$ and $\mathrm{P}$ are provided in the form of fertilizers which can impact AMF (Fester and Sawers 2011; Henrichs et al. 2017). In addition, fungicides and soil fumigants used in agriculture may eliminate or significantly affect the diversity and populations of AMF (Martinez and Johnson 2010). A good agricultural model system to examine AMF communities is onion (Allium cepa) production, as onion plants are highly dependent on AMF because of their relatively sparse, unbranched rooting system with minimal root hairs (Brewster 2008; Charron et al. 2001a, b). Previous studies have demonstrated that AMF can contribute to earlier maturity of onion plants with increased bulb quality, bulb firmness, and uniformity of bulb diameter, and reduced bulb shrinkage in storage (Charron et al. 2001a, b; Makus 2002). The extent of AMF colonization was correlated positively with onion yields in high input conventional onion crops as well as lower-input, certified organic onion crops in the Netherlands (Galván et al. 2009), illustrating that AMF can potentially enhance onion growth in lower or higher soil nutrient conditions. Bulb yield increased as much as $70 \%$ in response to AMF inoculation in some studies (Sharma et al. 2004). AMF inoculation in P-limited soil increased $\mathrm{P}$ uptake of onion plants by $\sim 250 \mathrm{~kg}$ of phosphate fertilizer ha ${ }^{-1}$ (Brewster 2008). AMF also were demonstrated to reduce onion white rot incidence and severity caused by the soilborne fungus Sclerotium cepivorum (Jaime et al. 2008; Torres-Barragán et al. 1996). Production of onion plants in soil amended with AMF alone or AMF coinoculated with the soilborne plant pathogen Rhizoctonia solani increased onion height compared with onions growing in the absence of AMF (Sharma-Poudyal et al. 2014). In one study, soilborne pathogens such as $R$. solani colonized onion roots more effectively in the absence of AMF (Afek et al. 1990).

Growers in the Columbia Basin of central Washington and northcentral Oregon produce onion bulb crops on approximately 10,000 ha annually with a value of $\$ 331$ million in 2016 (United States Department of Agriculture National Agricultural Statistics Service 2017). The Columbia Basin ranks second to third in the U.S. for production of storage onions annually, after California and the Treasure Valley of eastern Oregon and western Idaho, producing about $27 \%$ of the U.S. storage onions. However, the use of soil fumigation on approximately $90 \%$ of onion fields in the Columbia Basin, combined with relatively high rates of $\mathrm{P}$ fertilizer application (Pelter and Sorensen 2003) and the widespread use of fungicides (e.g., metalaxyl + thiram or metalaxyl + fludioxonil + azoxystrobin as onion seed treatments) might negate or adversely affect the symbiotic association of onion plants with AMF (du Toit et al. 2014). Approximately 400 ha of organic onions are produced each year in the Columbia Basin without the use of synthetic soil fumigants, conventional fungicide seed treatments, or high application rates of synthetic fertilizers. However, a preliminary survey of certified organic and conventional onion bulb crops in the Columbia Basin in 2013 revealed AMF were present in all fields surveyed, with the degree of AMF colonization ranging from 42 to $90 \%$ of the sampled root length and no significant difference in degree of AMF colonization between organic and conventional onion crops (Knerr et al. 2016). Based on these unexpected findings, this study utilized next-generation sequencing (pyrosequencing) to look at the diversity and composition of AMF in four conventional versus five organic onion crops in the Columbia Basin. Conventional onion crops are fertilized with synthetic fertilizer and typically are fumigated with metam sodium once every 3 to 4 years of crop rotation (Pelter and Sorensen 2003). Metam sodium breaks down into isothiocyanate, which is toxic to fungi. Synthetic fumigants and fungicides are not used in organic onion crops, which are fertilized with organic sources (e.g., composted animal manures and green manure crops).

Pyrosequencing also was used in this study to assess the potential effects of soil fumigation with metam sodium on AMF communities in conventional onion production. To this end, AMF community structure was compared in four pairs of conventional onion crops, with one field in each pair fumigated with metam sodium the fall prior to planting the onion crop, and the other field in each pair not fumigated. The prevalence of AMF in these fields was also assessed by quantifying AMF colonization of onion roots using a baiting method and by sampling plants from growers' onion crops. We hypothesized that, for onion crops in the Columbia Basin: (i) AMF communities are distinct and less diverse in conventional than organic crops, and (ii) fumigation of fields with metam sodium reduces $\mathrm{AMF}$ prevalence and diversity.

\section{MATERIALS AND METHODS}

Experiments and field sampling. Sample collection from organic and conventionally managed onion fields. Nine fields in the Columbia Basin, four under conventional management and five certified for organic production, were sampled to compare AMF communities in conventional versus organic onion production systems. Approximately $1 \mathrm{~kg}$ of soil was sampled to a depth of $15 \mathrm{~cm}$ from each of five sites within each field in late March or early April 2014 to assess the AMF community present in each field within a week prior to the grower planting an onion crop in April. The GPS coordinates of each site were recorded, and the soil samples stored at $4^{\circ} \mathrm{C}$ until processed as described below for baiting AMF. A subsample of the soil from each site was subjected to nutrient analysis by Soiltest Farm Consultants, Inc. (Moses Lake, WA). P (Olsen method), $\mathrm{pH}$, ammonia $\mathrm{N}$, nitrate $\mathrm{N}$, potassium (K), and organic matter were measured. To estimate the extent of AMF colonization of the commercial onion crop planted in each field, and to examine the AMF community composition colonizing the roots of these onion crops, five onion plants were sampled from each of the same five sites in each of the nine onion fields between 24 June and 2 July 2014, by digging up as much of the root system as possible, shaking off the soil, and storing the plants individually at $4^{\circ} \mathrm{C}$ until the roots could be processed as described below. Onion plants were at the mid-bulbing stage of growth at the time of sampling (five to seven true leaves/plant) (Brewster 2008). The cultivar planted and the specific management practices for each field were determined by the grower-collaborators, i.e., cultivar, irrigation, fertility, and other management practices differed among 
fields although the growers followed typical onion production practices for the Columbia Basin (Pelter and Sorensen 2003). All four conventional crops were grown with center pivot irrigation, whereas the five organic crops were grown with drip irrigation. The nine fields ranged in size from 20 to 50 ha.

Sample collection from fumigated and nonfumigated conventional onion fields. Eight conventional fields were sampled each of three times in the Columbia Basin, representing four pairs of fields under pivot irrigation: (i) soil samples were collected in autumn 2014 (15 September) to provide a baseline assessment of the AMF community prior to any of the fields being fumigated; (ii) soil samples were collected again in spring 2015 (18 March), no more than two weeks prior to the grower-cooperators planting onion seed, to determine the degree of change in the AMF community following autumn fumigation and winter conditions; and (iii) onion plant samples were collected in summer 2015 (11 June) at the midbulbing stage of onion crop growth. For each pair of fields, one field was fumigated with metam sodium applied by center pivot chemigation at 355 liters/ha in late September or early October 2014 (before soil temperatures dropped $<10^{\circ} \mathrm{C}$ ), and the other field was not fumigated. The fields in each pair were located 50 to $500 \mathrm{~m}$ apart, representing the same soil type. Each field (approximately 50 ha) was planted to a conventional onion crop in late March or early April 2015 and was subjected to similar onion production practices for this region (Pelter and Sorensen 2003) except for differences in fumigation. On the first two sampling dates (15 September 2014, pre-autumn fumigation; and 18 March 2015, prespring planting of onion crops), soil was collected from each of five sites in each field, and immediately baited in the greenhouse by planting with onions. Soil samples were collected from the same five sites (GPS coordinates recorded) in each field at each sampling date using the protocol described previously for the organic versus conventional study. A soil nutrient analysis was completed using a subsample of soil from each site in each field by Soiltest Farm Consultants, Inc. On 11 June 2015, approximately the mid-bulbing stage of growth (five to seven true leaves/plant), five onion plants were sampled from each of the same five sites in each of the eight fields, using the sampling protocol described above for collecting bulbs in organic and conventional fields. Cultivars differed among fields, and specific crop maintenance practices were determined by the growers but were typical for the Columbia Basin.

Evaluation of AMF colonization and community structure within organic versus conventional onion fields. Onions grown in soil samples under controlled environmental conditions were used to bait AMF from the soil samples. Baiting occurred within 1 month of sampling soil from each the nine onion fields sampled for the organic versus conventional comparison. A 500-g sample of the soil from each of the five replicate sites within each field was placed in a D40 deepot planting conetainer $(25 \mathrm{~cm}$ deep $\times 7 \mathrm{~cm}$ diameter, Stuewe \& Sons, Inc., Tangent, OR) in which the drain holes at the lower end had been sealed with paper towels. Water $(150 \mathrm{ml})$ was then added to the soil in each conetainer in $50 \mathrm{ml}$ increments. Ten onion seeds of the cultivar Talon (Bejo Seeds, Inc., Oceano, CA) were placed on the soil surface and covered with $17 \mathrm{~g}$ of dry soil from the same soil sample. Each tray of conetainers was then covered with brown Kraft paper for 7 days at $15 \pm 1^{\circ} \mathrm{C}$ with a $12 \mathrm{~h}$ photoperiod/day after arranging the conetainers in a completely randomized design for all fields sampled. After 7 days, the paper was removed, and the plants were maintained in the growth chamber for 60 days with $50 \mathrm{ml}$ of irrigation water added every 3 days or as needed. After 60 days, the plants (including the roots) were removed carefully from the conetainers and washed over a screen ( $\leq 2 \mathrm{~mm}$ aperture) using running tap water to remove the soil. The washed roots were removed from all the plants within a conetainer and then homogenized. For the five onion plants sampled directly from each of the five sites/field at the mid-bulbing growth stage midsummer, the roots were washed similarly over a screen and homogenized.

Half of the roots produced by the onion plants used to bait the soil samples, and half of the roots of the onion plants sampled directly from the fields, were frozen for DNA extraction. DNA was extracted from the roots using the PowerSoil kit (MoBio, Carlsbad, CA) with modification. Approximately $0.25 \mathrm{~g}$ of frozen root tissue was cut and homogenized using a flame-sterilized scalpel in a sterilized glass petri dish. Root samples were then lysed using a Fast-Prep 24 (MD Biomedical, Santa Ana, CA) at $6 \mathrm{~m} / \mathrm{s}$ for $1 \mathrm{~min}$. For the five plants sampled from each field site at mid-bulbing, the extracted DNA was pooled prior to sequencing. The presence of AMF DNA in the extracted DNA was confirmed by PCR assay as described below. DNA was then submitted to Mr. DNA (Shallowater, TX) following the company instructions for 454 pyrosequencing.

The presence or absence of AMF was also determined microscopically ( $10 \times$ to $20 \times$ magnification) for 45 root segments per site. Roots from the plants used for baiting soils and from the plants sampled directly from the fields were boiled for $15 \mathrm{~min}$ in $10 \%$ potassium hydroxide, stained for $3 \mathrm{~min}$ in a $5 \%$ Sheaffer black ink and vinegar solution, and then destained with vinegar (Verheilig et al. 1998). The incidence (\%) of root segments with AMF colonization was calculated using a modified gridline intersection method (Giovannetti and Mosse 1980) in which the root segments were laid over a $65 \mathrm{~mm} \times 25 \mathrm{~mm}$ clear plastic grid (with horizontal lines and vertical lines spaced $5 \mathrm{~mm}$ apart) placed on top of a $75 \mathrm{~mm} \times 25 \mathrm{~mm} \times 1.2 \mathrm{~mm}$ thick glass microscope slide. The presence or absence of AMF structures (internal hyphae as well as arbuscules and/or vesicles) was determined at each intersection along the length of each of the root segments examined microscopically, for a minimum of 40 root segments rated/plant. For plants sampled from the field at the mid-bulbing stage of development, the mean percentage AMF colonization of the roots was determined by averaging the percentage of colonization for the roots sampled from each of three plants/site instead of all five plants/site because of the large size of the roots and the very timeconsuming nature of quantifying root colonization in this manner.

Evaluation of AMF colonization and community structure in fumigated versus nonfumigated conventional onion fields. AMF were isolated from the soil samples collected in the autumn of 2014 (prior to half the fields being fumigated) and again in the spring of 2015 (prior to the fields being planted with onion crops) from the four pairs of fumigated and nonfumigated fields using the same baiting and DNA extraction methods described above, with modifications. In addition, the roots of plants sampled from each of the eight fields at the mid-bulbing stage of development were stained for root colonization as described above. For baiting AMF from the soil samples, a 20-cm-diameter plastic quilting frame and standard mesh window screen material (Saint-Gobain, Malvern, PA) were used to sieve $\sim 700 \mathrm{~g}$ of soil from each site sampled. One piece of mesh screen was used per soil sample, and the quilting hoop was washed with $70 \%$ ethanol between samples. Sieved soil was added to a D40 deepot planting conetainers (Stewe and Sons, Corvallis, OR) and $150 \mathrm{ml}$ of water was added to each conetainer in $50 \mathrm{ml}$ increments, as described above. Ten seeds of the onion cultivar Talon F1 were added to each conetainer using forceps that were cleaned with $70 \%$ ethanol between conetainers. A tablespoon of dry soil from the same soil sample was placed over the seeds. Each conetainer was then covered with a small plastic bag held in place with a rubber band. Conetainers were arranged in a randomized complete block design in a Conviron set at $15^{\circ} \mathrm{C}$ with a 
12-h photoperiod/day. After 1 week, the bags were removed and the soil and seed in each conetainer were irrigated with $25 \mathrm{ml}$ of water every 3 days or as needed. Onion plants were maintained under these conditions for 60 days. A weekly application of a modified Long Ashton fertilizer (Hewitt 1966) containing no P, $0.8 \mathrm{mM}$ $\mathrm{KNO}_{3}, \mathrm{Ca}\left(\mathrm{NO}_{3}\right)_{2} 4 \mathrm{H}_{2} \mathrm{O}$, and $0.75 \mathrm{mM} \mathrm{MgSO} 47 \mathrm{H}_{2} \mathrm{O}$ was initiated during the fifth week for soils sampled in autumn 2014 (prior to half of the fields being fumigated), and during the fourth week for soils sampled in spring 2015. After harvesting the plants as described above, half of the roots from each plant were stained and examined microscopically to quantify AMF colonization, and the other half were used for DNA extraction, with the DNA submitted for 454 pyrosequencing as described above. Onion plants sampled from the five sites in each of the eight fields were washed, the roots removed and homogenized, a composite root sample from each site stained, and the percentage of roots colonized by AMF determined microscopically as detailed above.

Statistical analysis of colonization data. Two-way analysis of variance (ANOVA) and mean comparisons for AMF root colonization were computed by field and system for the organic versus conventional comparison. A separate ANOVA by field and fumigation treatment was completed for the fumigated versus nonfumigated conventional field study. In both ANOVAs, fields were treated as random effects nested within cropping system or fumigation system. The analyses were completed with JMP Version 11 Pro (SAS Institute Inc., Cary, NC). Analysis of variance and mean comparisons of available $\mathrm{P}, \mathrm{pH}$, ammonia $\mathrm{N}$, nitrate $\mathrm{N}, \mathrm{K}$, and organic matter were computed with JMP Version 11 Pro (SAS Institute Inc., Cary, NC).

PCR amplification. A $300 \mathrm{bp}$ fragment of the 18S rDNA region was amplified from the roots of each baited soil sample or each set of field plants sampled using primers specific for AMF (Van Geel et al. 2014). The primers were AMV4.5NF (forward primer 5' AAGCTCGTAGTTGAATTTCG $3^{\prime}$ ) and AMDGR (reverse primer 5' CCCAACTATCCCTATTAATCAT $3^{\prime}$ ). The mix for each PCR reaction contained $7.75 \mu \mathrm{l}$ of sterilized water, $5 \mu \mathrm{l}$ of $5 \times$ GoTaq Flexi buffer (Promega, Madison, WI), $1.5 \mu \mathrm{l}$ of $25 \mathrm{mM} \mathrm{MgCl}_{2}$, $2.5 \mu \mathrm{l}$ of $2 \mathrm{mM}$ dNTPs, $3 \mu \mathrm{l}$ each of $10 \mu \mathrm{M}$ primers (Sigma, St. Louis, MO), $0.25 \mu$ l of GoTaq Flexi (Promega), and $2 \mu l$ of genomic DNA extract. The thermal cycler parameters were $94^{\circ} \mathrm{C}$ for $3 \mathrm{~min}$ for denaturing; followed by 35 cycles of $94^{\circ} \mathrm{C}$ for $45 \mathrm{~s}, 60^{\circ} \mathrm{C}$ for $45 \mathrm{~s}$, and $72^{\circ} \mathrm{C}$ for $1 \mathrm{~min}$; and a final extension at $72^{\circ} \mathrm{C}$ for $7 \mathrm{~min}$.

454 pyrosequencing. The barcoded amplicon sequencing process (bTEFAP) was completed by Mr. DNA as described by Dowd et al. (2008a, b), modified for the AMF-specific 18S primers detailed above. A single-step, 30-cycle PCR assay using HotStarTaq Plus Master Mix Kit (Qiagen, Valencia, CA) was used with the following conditions: $94^{\circ} \mathrm{C}$ for $3 \mathrm{~min}$; followed by 28 cycles of $94^{\circ} \mathrm{C}$ for $30 \mathrm{~s}, 53^{\circ} \mathrm{C}$ for $40 \mathrm{~s}$, and $72^{\circ} \mathrm{C}$ for $1 \mathrm{~min}$; after which a final elongation step at $72^{\circ} \mathrm{C}$ for 5 min was performed. Following the PCR assay, the amplified products from the different samples were mixed in equal concentrations and purified using Agencourt Ampure beads (Agencourt Bioscience Corp., MA). DNA samples were then sequenced utilizing a Roche 454 FLX titanium instrument and reagents following the manufacturer's guidelines.

Sequence analysis. Flowgrams from the 454 pyrosequencing were extracted from .sff files and trimmed to a minimum of 200 and a maximum of 360 flows, allowing for 1 and 2 differences in barcode and primer sequences, respectively. De-noising was performed on the USDA-ARS Scinet cluster in Mothur (v1.36.1) (Schloss et al. 2009) using the shhh.flows algorithm. Barcodes and primers were removed, and sequences with $<200 \mathrm{bp},>6$ ambiguous bases, and homopolymers $>6$ were discarded using the split_libraries.py script in QIIME v1.9.1 (Caporaso et al. 2010). Sequences were clustered into OTUs at $97 \%$ similarity with Usearch (v2.3.0) (Rognes et al. 2016) using a closed-reference algorithm against the MARJAAM database (Opik et al. 2010). Low-abundance OTUs ( $<5$ total sequences among all samples) were removed. OTU tables were rarefied to an even sampling depth of 522 sequences prior to analysis.

AMF community data analyses. Heat maps for AMF OTUs from baited soil samples and onion root samples collected from the organic and conventional fields, and from baited soil samples from the paired fumigated and nonfumigated fields were created in PRIMER 7 (Plymouth Routine in Multivariate Ecological Research) (2015 PRIMER-E Ltd., Lutton, Ivybridge, UK). Accompanying neighbor-joining phylogenies were estimated using MEGA7 (Molecular Evolutionary Genetics Analysis) version 7.0 (Kumar et al. 2015) with maximum composite likelihood analysis to compute evolutionary distances. Patterns of AMF community structure for all samples were described with nonmetric multidimensional scaling (NMDS). The NMDS algorithm was computed with a zero-adjusted Bray-Curtis similarity matrix (Clarke et al. 2006) at increasing dimensions $(\mathrm{k})$ until stress declined $<0.2$, the threshold below which the ordination plot accurately represents patterns in the original similarity matrix (Clarke 1993).

The null hypotheses that AMF community structure did not differ between organic and conventional onion cropping systems in the nine fields sampled in spring and summer 2014, or between fumigated and nonfumigated fields sampled in the autumn of 2014 (prefumigation) and in the spring of 2015 (postfumigation) were tested with permutational multivariate analysis of variance (PERMANOVA) (Anderson 2001) in PRIMER 7. The assumption of multivariate heteroscedasticity was tested and satisfied $(P \geq 0.12)$ for all data sets with the PERMDISP function in PRIMER 7. Since pre- and postfumigation samples were likely autocorrelated for that study, the independence of counts of each OTU from pre- and postfumigation samples was tested and satisfied $(P \geq 0.16)$ with Durban-Watson tests of autocorrelation using the "dwt" function in the "car" package in R (version 3.2.1, R Foundation for Statistical Computing, Vienna, Austria). For the spring baited soil samples and midsummer plant samples from the organic versus conventional onion production study, counts of $18 \mathrm{~S}$ reads were modeled as a function of cropping system and fields, with fields nested within cropping system. Cropping system was treated as a fixed effect and fields were treated as a random effect. For the fumigated and nonfumigated baited soil samples, $18 \mathrm{~S}$ reads were modeled as a function of fumigation status (fumigated versus nonfumigated), time sampled (autumn or prefumigation versus spring or postfumigation), and fields. Fields were nested within fumigation status. Fumigation and soil sampling time were treated as fixed effects while fields were treated as a random effect.

Posthoc comparisons between each OTU detected in conventional and organic fields were performed using Welch's $t$ tests with the "t.test" function in the "stats" package in R. Since no significant effect of fumigation (Pseudo- $F=0.14, P=0.9185$ ) was detected with PERMANOVA, posthoc comparisons between each OTU from pre- and postfumigation soil samples were performed without a fumigation effect using a one-way ANOVA with a Welch's correction using the "oneway.test" function in the "stats" package in R. The false discovery rate for all posthoc comparisons was controlled with a Bonferroni-type adjustment (Benjamini and Hochberg 1995) using the "p.adjust" function in the "stats" package in $\mathrm{R}$.

AMF richness, Shannon diversity (H') (Shannon 1975), and the inverse Simpson's diversity (1/D) (Simpson 1949) were calculated using the vegan package in $\mathrm{R}$ (version 3.2.1, R Foundation for Statistical Computing). These diversity indices incorporate and 
reflect both OTU richness and abundance (Morris et al. 2014). The Shannon diversity index is expressed as

$$
H^{\prime}=-\sum_{i=1}^{S} P_{i} \ln \left(P_{i}\right)
$$

where $P$ represents the proportion of OTU $i$ for all OTUs sampled and $S=$ Simpson's diversity index expressed as

$$
D_{1}=1-\sum_{i=1}^{s} p_{i}^{2}
$$

Both the Shannon diversity index and the inverse Simpson's diversity index increase in response to increased diversity, though the Shannon index emphasizes the richness component of diversity whereas the inverse Simpson's index emphasizes community evenness. AMF diversity metrics were compared between organic and conventionally managed cropping systems at each sampling time (spring-baited soil samples and midsummer plant samples) using Welch's $t$ tests. Welch's $t$ tests were also used to compare diversity between paired fumigated and nonfumigated fields for the autumn 2014 (prefumigated) baited soil samples. For the spring 2015 (postfumigation), baited soil samples, the effects of fumigation on AMF diversity were assessed using a nested ANOVA in which fumigation treatment was nested within paired fields.

\section{RESULTS}

Impact of organic versus conventional cropping system on soil properties. Overall, the five certified organic onion fields had significantly less available $\mathrm{P}$ compared with the four conventional onion fields sampled in 2014 (mean of 30 versus $49 \mathrm{ppm}, P<$ 0.001 ). Available $P$ levels ranged from 10 to $60 \mathrm{ppm}$ for the organic crops, and 17 to 71 for the conventional crops. The organic fields also had a significantly higher $\mathrm{pH}$ overall (mean of 7.78 versus 7.06 , $P<0.001$ ) and greater levels of ammonia N (mean of 4.93 versus $2.07 \mathrm{ppm}, P<0.030$ ). There were no significant differences between organic versus conventional onion crops in the available levels of nitrate $\mathrm{N}, \mathrm{K}$, or organic matter.

Impact of cropping system and fumigation on AMF colonization. AMF colonization was observed in onion roots for all five of the organic fields and all four conventional fields sampled in 2014 , both on the roots of onion plants used to bait the spring soil samples and on the roots of onion plants sampled midsummer from the onion crops. The mean percentage AMF colonization of baited roots from the five organic and four conventional fields ranged from 42.3 to $90.2 \%$ (Table 1 ). There was no significant difference in AMF root colonization $(P=0.910)$ between organic and conventional fields in the early spring baited greenhouse samples (Table 1). The roots of all onion plants sampled midsummer from the crops had AMF, regardless of conventional or organic management practices. The mean percentage root colonization by AMF for plants sampled from the commercial crops ranged from $7.3 \%$ (field C1) to $88.7 \%$ (field O1). There was significantly more extensive AMF root colonization in the organic fields compared with the conventional fields (67 versus $51 \%, P=0.020$ ) in the midsummer field samples (Table 1). Significant differences in AMF colonization between organic versus conventionally managed crops were only detected in the midsummer field samples. However, the mean percentage AMF colonization of roots of onion bait plants grown in spring soil samples was greater for six of the nine fields compared with AMF root colonization onion plants sampled from crops midsummer (1.5 to $29.8 \%$ greater colonization). The exceptions were fields $\mathrm{O} 4, \mathrm{C} 1$, and $\mathrm{C} 4$ for which the degree of $\mathrm{AMF}$ root colonization was similar for the two sets of samples (Table 1).

AMF colonization of onion roots was observed in all four fumigated fields and all four nonfumigated fields in the roots of onion plants used to bait AMF from soil samples collected in autumn 2014 (prior to fumigation of four of the fields), in the roots of onion plants used to bait soil samples collected in spring 2015 (prior to the growers planting onion crops in these fields), and in the roots of onion plants sampled midsummer from the onion crops (Table 1). Although AMF colonization in onion roots sampled from the crops in midsummer was significantly less in the fumigated fields than the nonfumigated fields (45 versus 67\%) (Table 1), there were no significant differences in AMF colonization of onion roots from the baited soil samples collected before fumigation in the fall of $2014(P=0.359)$ or in the early spring samples of 2015 ( $P=0.891)$. AMF colonization of the roots also varied among the fields and among sampling times (Table 1). For the fall 2014 soil samples, colonization of the roots of the bait plants ranged from 38.0 to $87.6 \%$. For only two fields was the AMF root colonization level $<55 \%$ ( $38.0 \%$ for field F1 and $54.4 \%$ for field NF2) compared with 71.5 to $87.6 \%$ for the other six fields, with no difference among these fields. For the spring 2015 soil samples, AMF root colonization on the bait plants ranged from 22.5 to $61.2 \%$, with the least root colonization in fields F1 (22.5\%) and NF3 (31.2\%), and no significant difference in colonization levels for the other six fields. For six of these eight fields, there was a significant decrease in AMF colonization detected in onion roots used to bait the spring 2015 soil samples compared with that of the fall soil samples. The decrease in root colonization levels from fall to spring ranged from 15.5 to $54.5 \%$ for those six fields (Table 1). The two fields for which there was no significant decrease in root colonization in fall versus spring soil samples included one fumigated field (F2) and one nonfumigated field (NF2).

For onion plants sampled midsummer from onion crops in the fumigated and nonfumigated conventional onion fields, the degree of AMF colonization ranged from 14.4 (field F1) to $80.3 \%$ (field NF4) (Table 1). There was no apparent difference in root colonization levels for the spring 2015 baited soils versus mid-June onion plants sampled from nonfumigated field NF1, but colonization levels increased from the March to June 2015 samples for five of the eight fields (two fumigated and three nonfumigated), ranging from an increase of $11.2 \%$ for field $\mathrm{F} 3 ; 25.9 \%$ for field NF4; and decreased significantly over this timeframe for two fumigated fields (from 22.5 to $14.4 \%$ for $\mathrm{F} 1$ and from 59.1 to $35.8 \%$ for $\mathrm{F} 4$ ).

AMF community sequencing. After processing, 652,363 DNA sequences from all samples clustered into 51 AMF OTUs. Overall, most sequences were classified to species of Glomus (66\% of sequences; 35 OTUs), followed by Claroideoglomus (28\% of sequences, 6 OTUs), Acaulospora (5\% of sequences, 1 OTU), Diversispora ( $0.7 \%$ of sequences, 7 OTUs), and Paraglomus $(0.5 \%$ of sequences, 3 OTUs). In general, samples from both the organic versus conventional survey and the fumigated versus nonfumigated field survey were dominated by Glomus species, though sequences from some individual samples primarily belonged to other genera, such as Claroideoglomus and Acaulospora (Figs. 1A, 2A, and 3A).

Effects of organic versus conventional cropping systems on AMF diversity. A number of the AMF OTUs present in onion roots in the organic fields were not detected in the conventional fields, regardless of sampling date, i.e., whether baiting for AMF from soil sampled in early spring before planting (Fig. 1A), or sampling roots midsummer from plants in the fields (Fig. 2A). However, the relative abundance of several of the AMF OTUs, e.g., Glomus mosseae (Funneliformis mosseae), G. Whitfield type 17, and Claroideoglomus lamellosum, remained relatively constant between the organic and conventional cropping systems (Figs. 1A and 2A). Notably, these taxa also tended to be highly abundant, 
suggesting that the largest portion of the AMF community was similar in the two cropping systems. There was no visible congruence between OTU phylogeny and relative abundance of OTUs depicted in the heat maps (Figs. 1A and 2A).

For spring-baited soils, AMF communities in the organic fields were separated from those of conventional fields along axis 3 of the NMDS plot (Fig. 1B). For AMF communities detected midsummer in onion root samples, AMF communities in organic fields were separated from those in conventional fields along axis 2 of the NMDS plot (Fig. 2B). Three dimensions were required to preserve the original similarities (stress <0.2) (Clarke 1993) for both sets of samples (Figs. 1B and 2B). Differences in AMF communities observed in the NMDS plots were supported by PERMANOVA results (Table 2). For spring-baited soil samples, AMF community structure was not significantly different (Pseudo- $F=1.67, P=$ 0.1252 ) between organic and conventional cropping systems but was different among fields (Pseudo- $F=3.90, P=0.0001$ ) (Table 2). In contrast, there was evidence that midsummer (field onion) root samples differed in AMF community structure between organic and conventional cropping systems (Pseudo- $F=3.59, P=0.0146$ ), as well as among fields (Pseudo- $F=6.44, P=0.0001$ ) (Table 2). Counts of three AMF OTUs, Diversispora MO GC1, Glomus Alguacil10 Glo6, and Glomus Sanchez Castro12b GLO12, from the midsummer root samples were significantly greater in organic fields than conventional fields $(P \leq 0.042)$.

Although AMF communities from the roots of onion bait plants grown in soil sampled in early spring from organic and conventionally managed fields did not differ significantly in AMF diversity as measured by Shannon's index or inverse Simpson's index, those from the organic soils had significantly greater richness of AMF (Table 3). For onion roots collected midsummer, conventionally managed fields had significantly less AMF diversity (Shannon's index and inverse Simpson's index) as well as significantly less AMF richness than the roots from organic fields, as the roots from organic fields harbored on average almost twice as many AMF OTUs than those from conventional fields (Table 3).

Effects of soil fumigation on AMF communities. In contrast to changes in AMF relative abundance in the organic versus conventional

TABLE 1

Comparison of the mean \pm standard deviation of the percentage arbuscular mycorrhizal fungi (AMF) colonization of onion roots in organic versus conventional fields sampled in 2014, and in fumigated versus nonfumigated conventional onion fields sampled in 2014 and 2015 in the Columbia Basin of the Pacific Northwest United States ${ }^{v}$

\begin{tabular}{|c|c|c|c|c|}
\hline Field & Management & \multicolumn{2}{|c|}{$\begin{array}{l}\text { Onions used to bait soil samples } \\
\text { collected in early spring } 2014^{\mathrm{w}}\end{array}$} & $\begin{array}{l}\text { Onion plants sampled from } \\
\text { the field midsummer }\end{array}$ \\
\hline \multicolumn{5}{|l|}{ Organic versus conventional fields ${ }^{y}$} \\
\hline 01 & Organic & \multicolumn{2}{|c|}{$90.2 \pm 5.6 \mathrm{a}^{\mathrm{z}}$} & $88.7 \pm 2.5 \mathrm{a}$ \\
\hline $\mathrm{O} 2$ & Organic & \multicolumn{2}{|c|}{$85.5 \pm 13.9 \mathrm{ab}$} & $71.2 \pm 6.8 \mathrm{bc}$ \\
\hline O3 & Organic & \multicolumn{2}{|c|}{$75.0 \pm 12.4 \mathrm{abc}$} & $51.5 \pm 10.6 d$ \\
\hline O4 & Organic & \multicolumn{2}{|c|}{$69.4 \pm 14.2 \mathrm{bc}$} & $79.9 \pm 4.1 \mathrm{abc}$ \\
\hline $\mathrm{C} 1$ & Conventional & \multicolumn{2}{|c|}{$42.3 \pm 19.7 d$} & $50.5 \pm 7.6$ de \\
\hline $\mathrm{C} 2$ & Conventional & \multicolumn{2}{|c|}{$88.2 \pm 7.1 \mathrm{a}$} & $7.3 \pm 3.9 f$ \\
\hline C3 & Conventional & \multicolumn{2}{|c|}{$89.3 \pm 8.4 a$} & $64.9 \pm 13.6 \mathrm{~cd}$ \\
\hline C4 & Conventional & \multicolumn{2}{|c|}{$80.9 \pm 19.6 \mathrm{abc}$} & $83.3 \pm 3.9 a b$ \\
\hline \multicolumn{5}{|l|}{$\begin{array}{l}\text { Fumigated versus nonfumigated } \\
\text { conventional fields }\end{array}$} \\
\hline F1 & Fumigated & $38.0 \pm 7.6 \mathrm{c}$ & $22.5 \pm 8.5 \mathrm{c}$ & $14.4 \pm 16.6 \mathrm{e}$ \\
\hline $\mathrm{F} 2$ & Fumigated & $71.5 \pm 12.0 \mathrm{ab}$ & $61.2 \pm 12.0 \mathrm{a}$ & $74.4 \pm 15.1 \mathrm{ab}$ \\
\hline F3 & Fumigated & $87.6 \pm 5.2 \mathrm{a}$ & $47.0 \pm 5.2 a b c$ & $58.2 \pm 6.8 \mathrm{bc}$ \\
\hline F4 & Fumigated & $85.7 \pm 8.2 \mathrm{a}$ & $59.1 \pm 8.2 \mathrm{a}$ & $35.8 \pm 20.8 d$ \\
\hline NF1 & Nonfumigated & $79.6 \pm 4.1 \mathrm{a}$ & $59.9 \pm 4.1 \mathrm{a}$ & $63.5 \pm 25.9 \mathrm{abc}$ \\
\hline NF2 & Nonfumigated & $54.4 \pm 7.2 \mathrm{bc}$ & $52.0 \pm 7.2 \mathrm{ab}$ & $73.0 \pm 6.9 \mathrm{abc}$ \\
\hline NF3 & Nonfumigated & $85.7 \pm 4.4 a$ & $31.2 \pm 4.4 b c$ & $53.0 \pm 11.3 \mathrm{~cd}$ \\
\hline
\end{tabular}


onion fields, fewer AMF OTUs differed in relative abundance in the pre- versus postfumigation soil samples collected from conventional onion fields. AMF OTUs were relatively conserved across sampling times (Fig. 3A). Similar to AMF communities in the organic versus conventional fields surveyed, the same core OTUs, G. mosseae (F. mosseae), Glomus Whitfield type 17, and C. lamellosum, were conserved across pre- and postfumigation soil samples, and no congruence was observed between phylogenetic clades in terms of abundance of OTUs (Fig. 3A).
AMF communities from fumigated versus nonfumigated conventional onion fields were not separated clearly by any axis on the NMDS plot; however, AMF communities in pre- versus postfumigation soil samples were separated by axis 3 (Fig. 3B). Three dimensions were also required to preserve the original similarities (stress <0.2) (Clarke 1993) in the NMDS plot (Fig. 3B). There was strong evidence that AMF communities differed between sampling times (Pseudo- $F=6.81, P=0.0001$ ) and among fields within fumigation system (Pseudo- $F=12.27, P=0.0001$ ), but not between
A

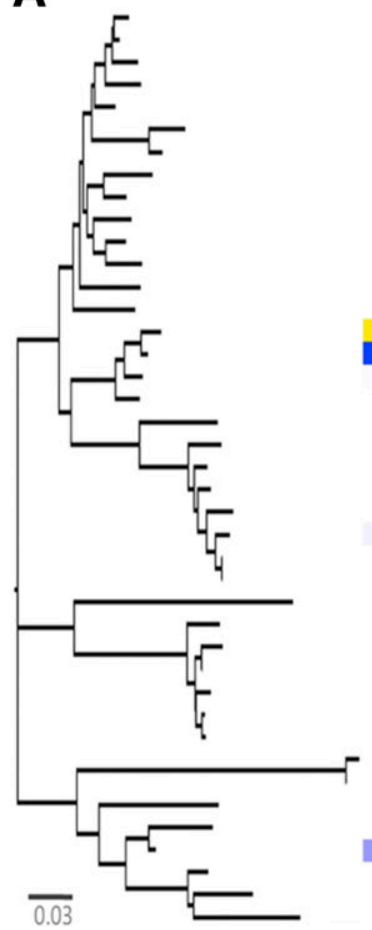

B

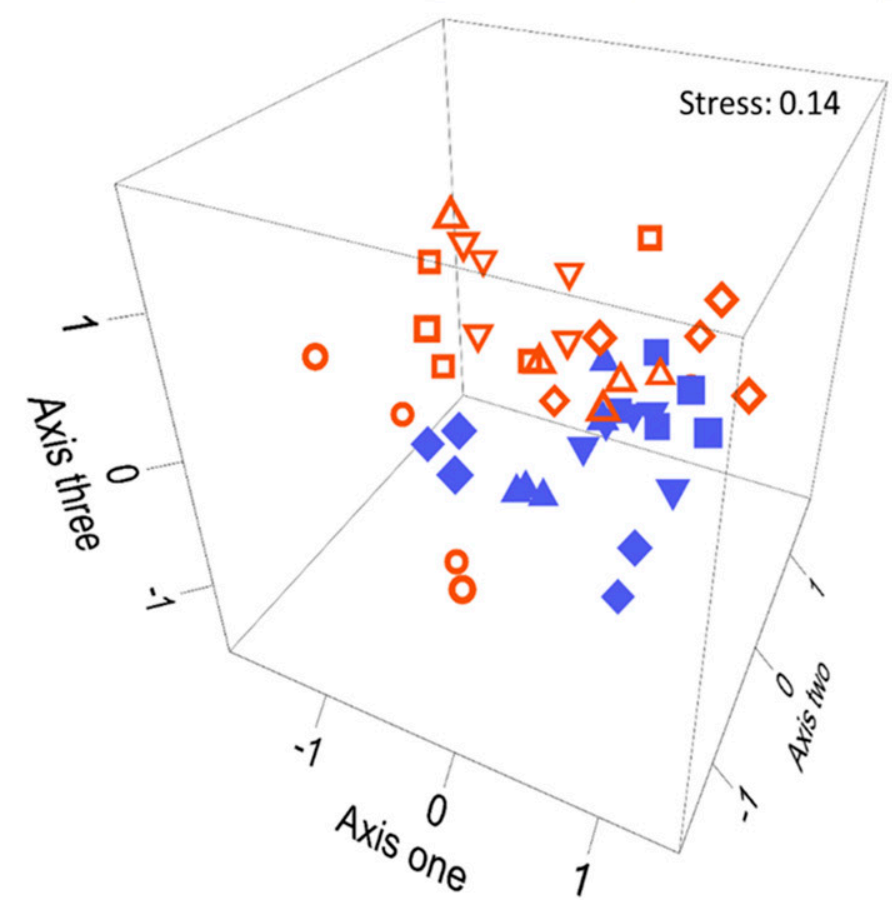

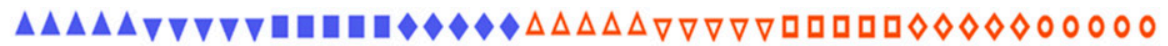

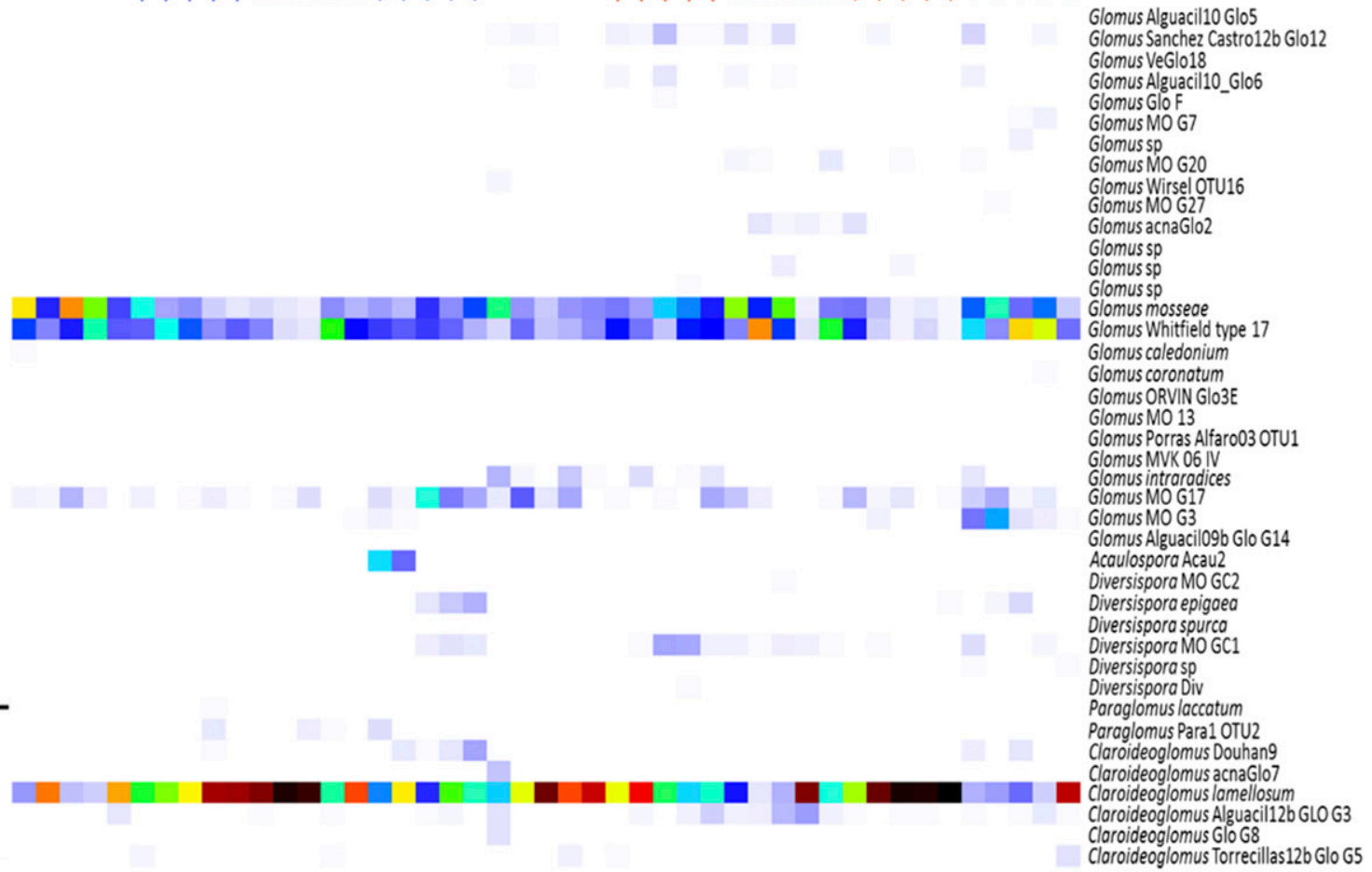

Fig. 1. Heat map of A, rarefied counts of 18 S reads of arbuscular mycorrhizal fungi (AMF) communities from spring-baited soil samples, and $\mathbf{B}$, nonmetric multidimensional scaling plot illustrating the similarity of the AMF communities in conventional versus organic onion fields in the Columbia Basin of the Pacific Northwest United States. 
fumigated and nonfumigated fields (Pseudo- $F=0.14, P=0.9185$ ) (Table 4). Counts of Glomus Whitfield type 17 were greater in prefumigation soil samples than postfumigation soil samples $(P=0.0182)$, while counts of $G$. mosseae ( $F$. mosseae) were greater in postfumigation soil samples than prefumigation soil samples $(P=0.0189)$.

For the autumn soil samples (prefumigation) baited for AMF by planting onion seed, Shannon's index, the inverse Simpson's index, and richness of AMF varied significantly among fields (ANOVA
$\mathrm{F}=3.46,2.68$, and 3.48 at $P=0.009,0.030$, and 0.008 , respectively). However, within each pair of fields, only AMF communities from the two fields in pair A differed significantly in richness and Shannon's diversity (Table 5). This suggests that, in general, paired fields were similar in AMF diversity prior to soil fumigation with metam sodium in the autumn.

For the spring soil samples (postfumigation) baited for AMF by planting onion seed, Shannon's index, inverse Simpson's index,
A

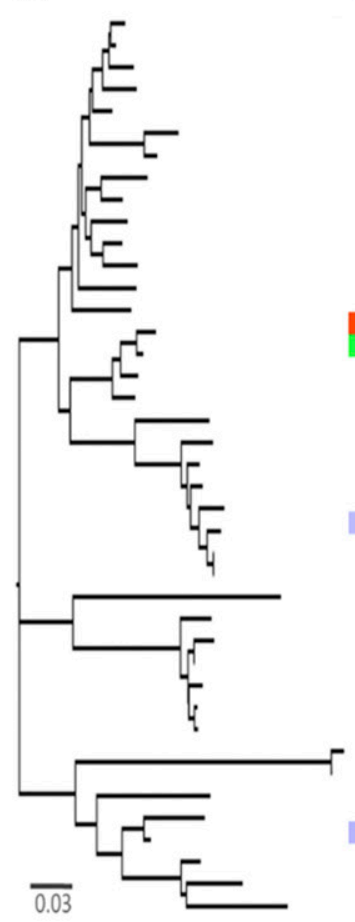

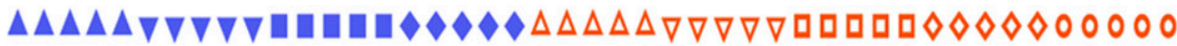

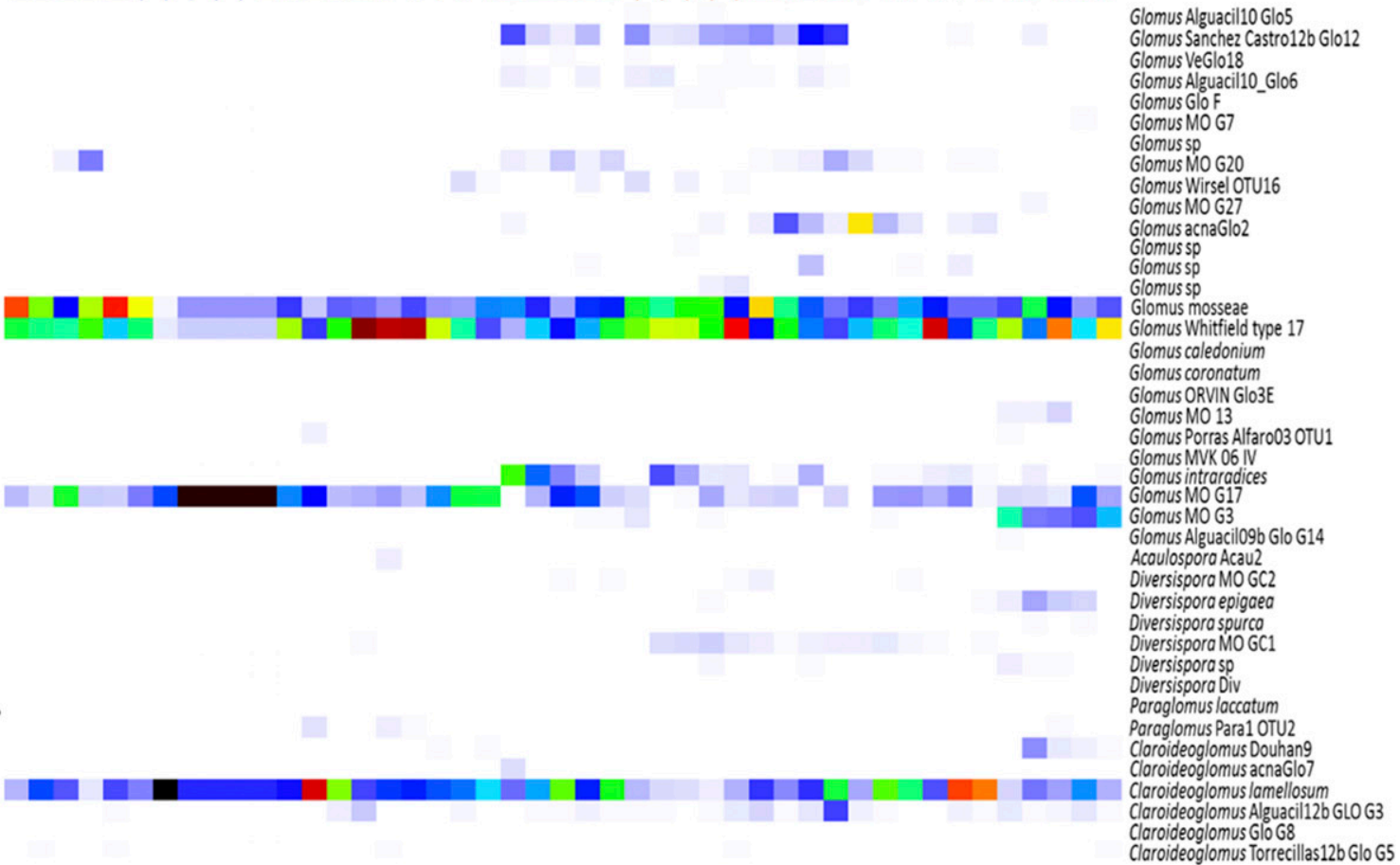

B

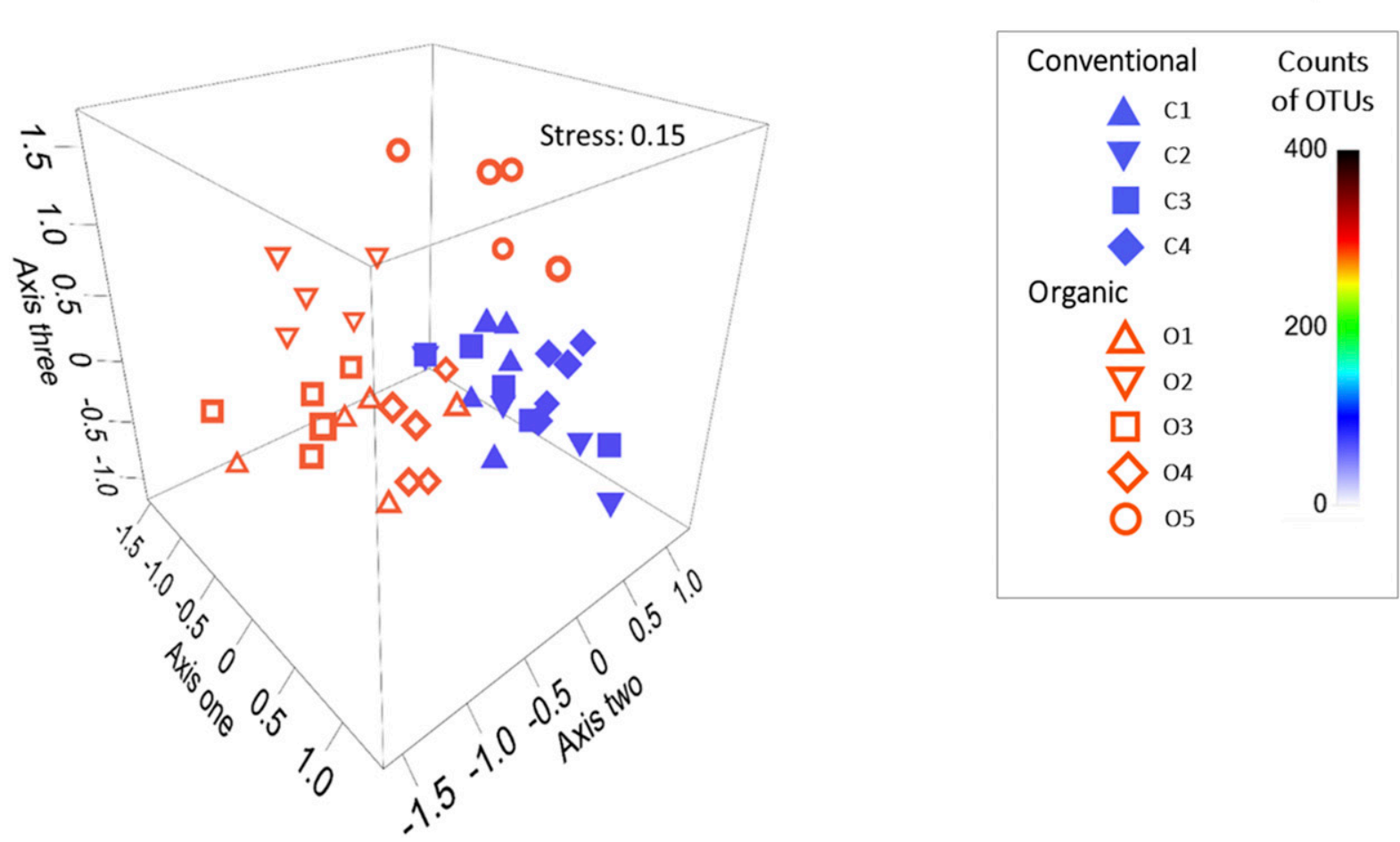

Fig. 2. Heat map of A, rarefied counts of $18 \mathrm{~S}$ reads of arbuscular mycorrhizal fungi (AMF) communities from midsummer onion root samples and $\mathbf{B}$, nonmetric multidimensional scaling plot illustrating the similarity of the AMF communities in conventional versus organic onion fields in the Columbia Basin of the Pacific Northwest United States. 
and richness of $\mathrm{AMF}$ again varied significantly among fields (ANOVA F $=22.72,13.95$, and 12.24 at $P<0.0001,0.0001$, and 0.0001 , respectively). Fumigation had a significant impact on AMF diversity (Shannon's index $\mathrm{F}=4.03$ at $P=0.02$ and inverse Simpson's index $\mathrm{F}=3.08$ at $P=0.052)$, but not AMF richness $(\mathrm{F}=$ 1.63 at $P=0.22$ ). In general, fumigated fields were less diverse and species-rich than the nonfumigated paired field, although missing data for pairs $\mathrm{A}$ and $\mathrm{C}$ limited the ability to detect significant differences (Table 5).

\section{DISCUSSION}

Examination of root colonization by AMF, counts of AMF spores, and estimation of AMF hyphal length have been standard techniques to determine the effects of agricultural management practices on AMF (Martinez and Johnson 2010). There is abundant literature showing how agricultural practices can influence populations of AMF fungi, especially tillage, $\mathrm{P}$ and $\mathrm{N}$ fertilization, and limited diversity of host plants in agricultural crop rotation systems

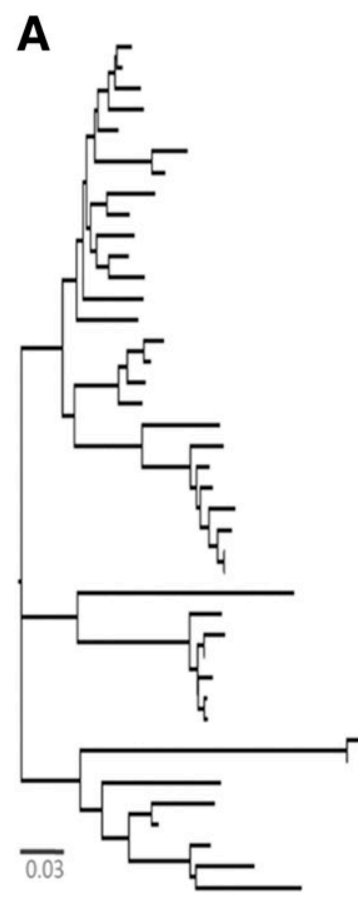

B

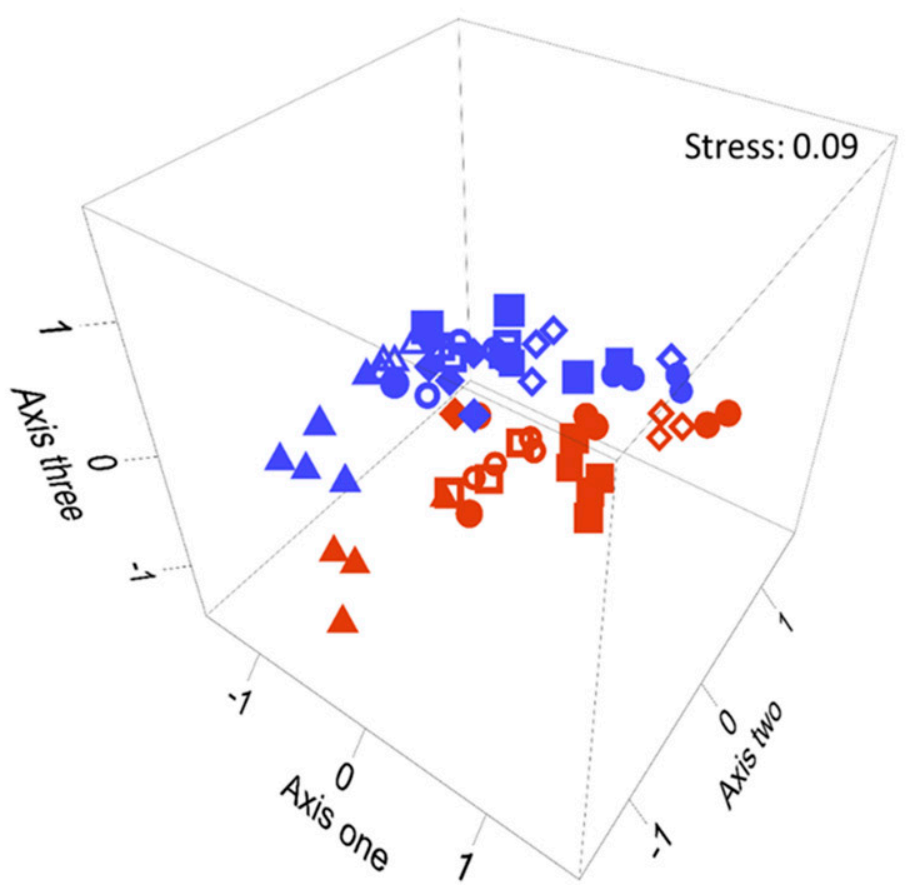

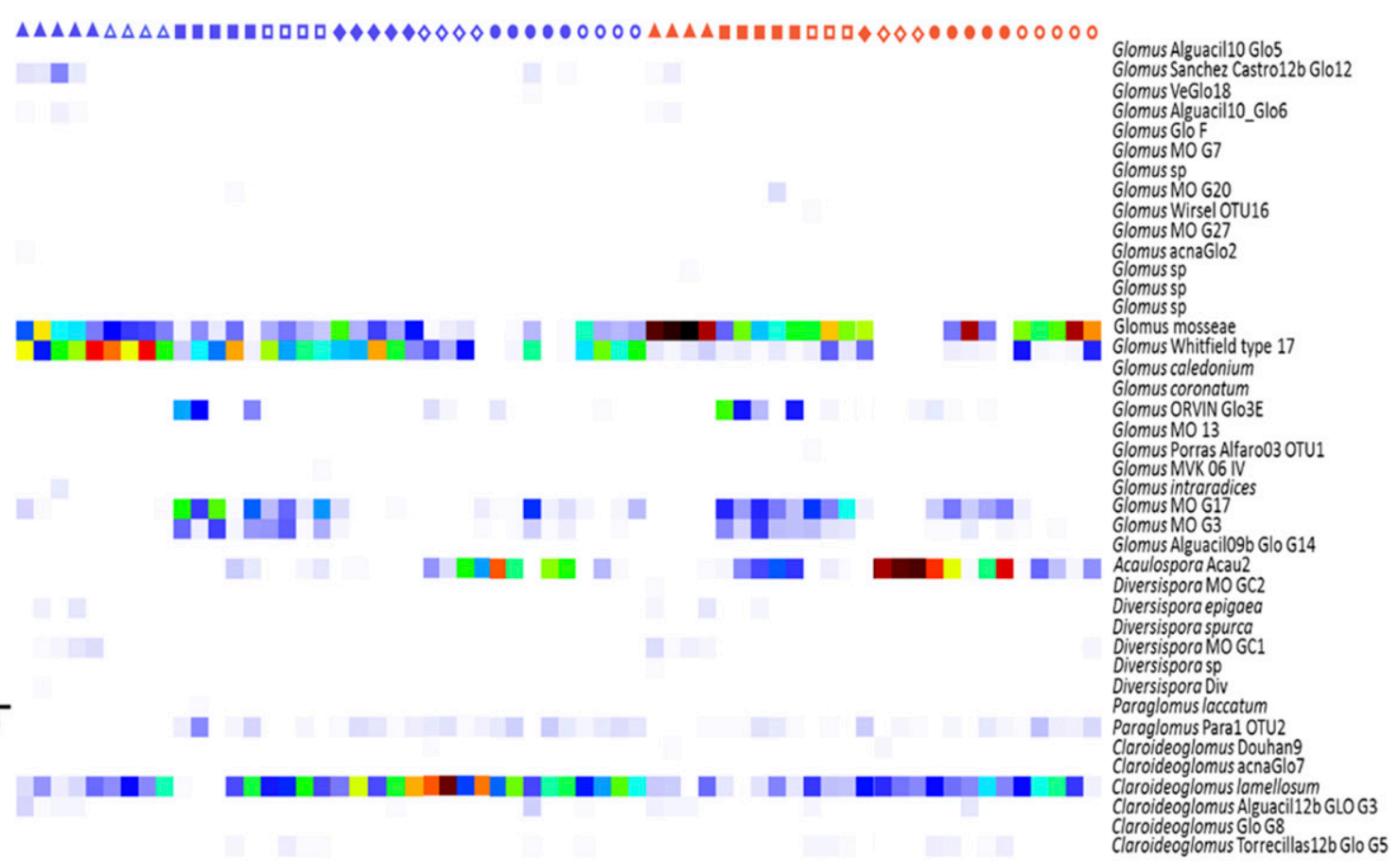

Fig. 3. Heat map of A, rarefied counts of $18 \mathrm{~S}$ reads of arbuscular mycorrhizal fungi (AMF) communities from pairs of fields sampled before and after fumigation of one field in each pair, and B, nonmetric multidimensional scaling plot illustrating the similarity of the AMF communities from fumigated (open symbols) and nonfumigated (solid symbols) fields sampled before (blue) and after (red) fumigation with metam sodium in the Columbia Basin of the Pacific Northwest United States. 
(Fester and Sawers 2011). In this study comparing organic versus conventional onion production practices, tillage practices were similar but $\mathrm{P}$ fertilizer practices differed in that synthetic $\mathrm{P}$ fertilizers are not used in certified organic production. Growers of both conventional and organic onion crops in this region may use autumn applications of composted manures, but growers of organic crops can only use certified organic fertilizers, e.g., 4-4-4 Perfect Blend Fertilizer (Perfect Blend LLC, Bellevue, WA). In addition, certified organic cover crops commonly are grown in the autumn prior to planting onion bulb crops the following spring, to serve as a source of organic material for the very sandy soils typical of this region. For instance, mustard biofumigant crops are grown widely for the biofumigation benefits of reduced pressure from some soilborne pathogens, insect pests, and weeds (Pelter and Sorensen 2003). These organic biofumigant crops have similar effects to metam sodium synthetic fumigant used in conventional onion production and may decrease AMF populations in certified organic production systems. Another difference is that growers of certified organic onion crops do not use synthetic pesticides, including soil fumigants. In this survey, AMF were detected on every onion plant examined, regardless of cropping system or field. There were significant differences in the amount of AMF colonization of onion roots in organic versus conventional crops and in some of the fumigated versus nonfumigated conventional onion crops, but only in the midsummer plant samples taken from onion crops in those fields. Although statistically significant, these differences were not large. This was not anticipated since the use of soil fumigants such as metam sodium was expected to be associated with reduced colonization of onion plants by AMF in conventional onion fields. However, it is a fairly common practice for organic onion crops in the Columbia Basin to be preceded by mustard biofumigant cover crops that are planted in late summer and then flail-mowed and incorporated into the soil in late autumn, prior to the first hard freeze and seed set of the mustard crop (Pelter and Sorensen 2003). These brassica biofumigant crops are of cultivars bred for high concentrations of glucosinolates that are converted by the enzyme myrosinase into active biofumigant products, isothicyanates, i.e., the same breakdown products as synthetic metam sodium used commonly for soil fumigation preceding the planting of a majority of conventional onion crops in the Columbia Basin. The biofumigant properties were once speculated to be responsible for the nonhost status of most Brassicaceae plants to AMF (Schreiner and Koide 1993a, b), although research has demonstrated this not to be true (Ludwig Muller et al. 2002; Pellerin et al. 2007).
Gosling et al. (2010) found that organic onion production practices in the United Kingdom resulted in greater AMF spore numbers and more extensive AMF colonization of onion plants compared with conventional production practices. In this survey of onion crops in the Columbia Basin of the Pacific Northwest United States, four genera of AMF were found to be dominant, primarily Glomus spp. but also a few OTUs of Clariodeoglomus, Diversispora, and Acaulospora. Glomus is one of the most common genera of AMF in agricultural systems (Cheng and Baumgartner 2004).

There was no significant difference between the AMF communities in organic versus conventional onion fields based on the PERMANOVA analysis. However, there was a strong influence of field location on AMF communities. This is not surprising given that AMF communities have been demonstrated to be heterogeneous spatially (Davison et al. 2012). In contrast to the PERMANOVA results, examination of the AMF communities using ordination of NMDS indicated that the communities differed between organic and conventional fields, especially AMF detected by pyrosequencing of DNA extracted from the roots of onion plants sampled midsummer from crops in these fields. The most abundant OTUs, C. lamellosum, G. mosseae (F. mosseae), and Glomus type Whitfield, did not differ between the organic and conventional fields. In a survey of organic and conventional onion fields in the Netherlands, Galván et al. (2009) identified 14 AMF phylotypes using sequencing of the $18 \mathrm{~S}-\mathrm{ITS} 1-5.8 \mathrm{~S}-\mathrm{ITS} 2$ region of rDNA. The number of phylotypes ranged from one to six per field, with a similar number of phylotypes per field and similar Shannon diversity indices in organic and conventional farming systems. The two phylotypes associated with $G$. mosseae-coronatum and G. caledonium-geosporum species complexes were the most abundant, with other phylotypes found infrequently (Galván et al. 2009). Climatic conditions and agricultural production practices associated with annual cropping systems in the Columbia Basin, including onion bulb crops, are very different than those associated with onion production in the Netherlands, illustrating the capacity for some AMF to persist in a wide diversity of agroecosystems.

Some of the less abundant AMF OTUs detected in this study were only present in the organic crops, e.g., G. intraradices (renamed recently as Rhizophagus irregularis), Glomus Sanchez_Castro_12b, and Diversispora_MO_CG1. It was surprising that DNA of $G$. intraradices was not detected in conventional onion crops in this study. $G$. intraradices has been researched extensively, has a worldwide distribution, and has been used as inoculum in various AMF studies (Berruti et al. 2016; Opik et al. 2008). Some fertilizers

TABLE 2

Permutational multivariate analysis of variance table for arbuscular mycorrhizal fungal communities from spring-baited soil samples collected in March-April 2014, and from plants sampled midsummer from certified organic and conventional onion fields in the Columbia Basin of the Pacific Northwest United States

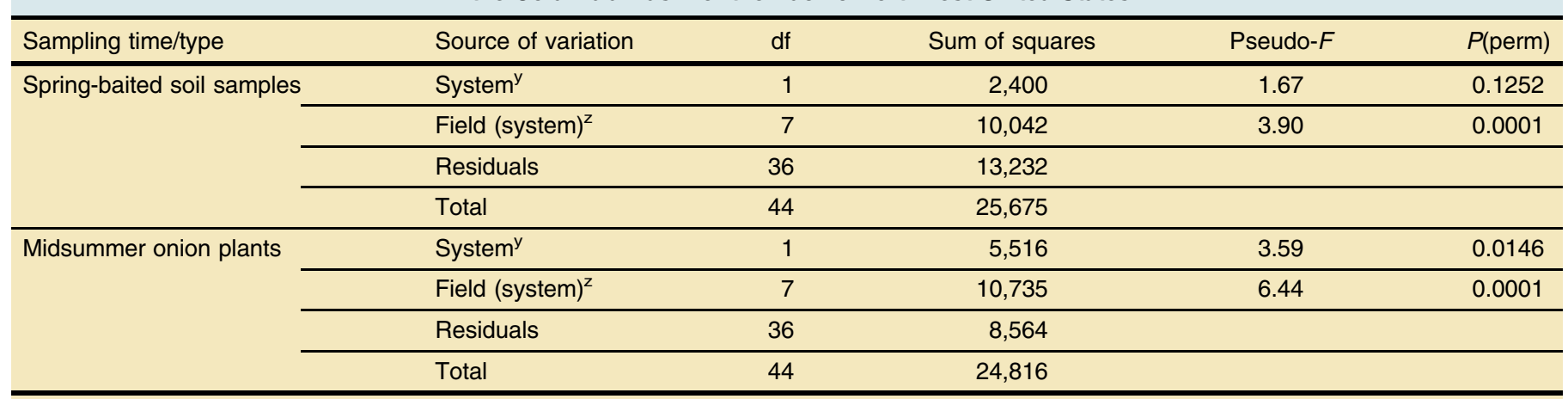

y System = certified organic versus conventional onion crops.

z Fields nested within onion production system, i.e., five organic onion crops and four conventional onion crops. 
used for organic onion crops in the Columbia Basin are amended with AMF inoculants, which contain species such as $R$. irregularis (Perfect Blend LLC).

When onion plants were sampled midsummer from crops in the Columbia Basin, a greater diversity and richness of AMF OTUs were detected compared with the OTUs detected from baited early spring soil samples. In addition, significant differences in OTU diversity and richness were detected between the organic and conventional onion crops for the midsummer plant samples. The same three most abundant OTUs detected in the spring baited soil samples were present in the midsummer onion plant samples, along with Glomus MO 317. As for the early spring baited soil samples, these most abundant OTUs did not differ significantly between the organic and conventional fields, but there were a number of OTUs of low abundance that were only detected in the onion roots sampled from organic fields (Diversispora MO CGL, Glomus acna GL2, G. intraradices, and Glomus Sanchez_Castro_12b). In the survey of onion fields in the Netherlands by Galván et al. (2009), a few organic and conventional fields had a greater number of phylotypes, determined by sequencing the 18S-ITS1-5.8S-ITS2 region of rDNA. This included phylotypes associated with Glomus-B, Archaeospora, and Paraglomus. Similar to the Columbia Basin onion survey, that study illustrated the variation in AMF communities that can occur among fields, even within similar farming systems.

Unlike the significant effects on AMF communities associated with the organic versus conventional onion fields surveyed in the Columbia Basin, there was a less distinct effect on AMF communities of soil fumigation with metam sodium in the autumn compared with no fumigation in conventional onion bulb crops surveyed. Every onion bait plant grown in soil collected in the autumn, prior to fumigation, and every bait plant grown in soil collected in the spring, after fumigation, as well as every onion plant sampled midsummer from all eight fields, was colonized by AMF. There were significant differences in extent of AMF colonization between fumigated versus nonfumigated fields, but only at the final, midsummer sampling time. In only two of the four pairs of fumigated and nonfumigated fields sampled was there less AMF diversity and richness in the fields fumigated with metam sodium compared with fields that were not fumigated. Otherwise there was no significant difference in AMF communities between fumigated and nonfumigated fields based on the NMDS plots and PERMANOVA. These results suggest that chemigated application of metam sodium through center pivots, the primary method of application of metam sodium in overhead irrigated onion crops in the Columbia Basin, has a limited effect on persistence of AMF in these soils. This may reflect the limited depth of movement of the fumigant into the soil with this method of application, limited efficacy of metam sodium applied in this manner at killing AMF spores, and/or potential rapid recolonization of the soil profile by
AMF fungi. However, the postfumigation soil samples baited for AMF were collected prior to growers planting onion seed in those eight fields, i.e., prior to AMF spores deeper in the soil profile being able to recolonize onion roots in the depth of the soil profile that was fumigated with metam sodium in four of the eight fields. Therefore, it appears that chemigation of metam sodium by center pivot had very limited effects on AMF communities in onion bulb crops in the Columbia Basin.

Results for AMF colonization levels of onion roots and AMF community analyses in fields among sampling times were confounded in this study by the use of different AMF detection methods at the different sampling times. The soil samples collected prior to the growers planting onion crops in these fields were baited by planting seed of an onion cultivar in the soil samples and growing the onions for 8 weeks at $15^{\circ} \mathrm{C}$, to reflect average soil and air temperatures in spring in this region. In contrast, AMF colonization and community analyses midseason were assessed using onion plants sampled directly out of the growers' crops, i.e., the AMF detected reflected only those that had colonized the onion plants. Onion cultivar, crop rotation history and specific production practices differed among fields surveyed, although these growers used typical production practices for organic or conventional onion crops in this region (Pelter and Sorensen 2003). Despite these confounding effects of sampling methods with sampling times, the degree of AMF colonization of onion roots, the predominant AMF OTUs identified, and overall characteristics of the AMF

TABLE 4

Permutational multivariate analysis of variance table for arbuscular mycorrhizal fungal communities from pairs of fumigated and nonfumigated onion fields in the Columbia Basin of the Pacific Northwest United States sampled before and after fumigation

\begin{tabular}{lrccc}
\hline Source of variation & df & Sum of squares & Pseudo- $F$ & $P($ perm $)$ \\
\hline Fumigation $^{\mathrm{x}}$ & 1 & 275 & 0.14 & 0.9185 \\
\hline Time $^{\mathrm{y}}$ & 1 & 2,305 & 6.81 & 0.0001 \\
\hline Field (fumigation) $^{\mathrm{z}}$ & 9 & 37,364 & 12.27 & 0.0001 \\
\hline Residuals & 50 & 16,909 & & \\
\hline Total & 61 & 62,053 & & \\
\hline
\end{tabular}

$\times$ Fumigation $=$ pairs of fields fumigated with metam sodium or not fumigated in the autumn of 2014, prior to planting the fields with onion bulb crops in spring 2015. Refer to the main text for details on sampling soil and plants from each field.

y Time $=$ time at which soil samples were collected from five sites/field in (i) the autumn of 2014 (September), a week or two prior to four of the eight fields being fumigated with metam sodium by chemigation, and (ii) the spring of 2015 (March), within a week or two of the fields being planted to conventional onion crops by growers.

z Fields nested within onion production system, i.e., four fumigated fields and four nonfumigated fields.

TABLE 3

Diversity (mean \pm standard deviation) of arbuscular mycorrhizal fungi in certified organic and conventional onion crops in the Columbia Basin of the Pacific Northwest United States

\begin{tabular}{llllr}
\hline Experiment & \multicolumn{1}{c}{ Management } & Shannon $\left(H^{\prime}\right)$ & Inverse Simpsons $(1 / \mathrm{D})$ & Richness $(\mathrm{S})$ \\
\hline Spring-baited soil samples & Conventional $(n=20)$ & $0.95 \pm 0.37 \mathrm{a}^{\mathrm{z}}$ & $2.27 \pm 0.85 \mathrm{a}$ & $5.20 \pm 1.58 \mathrm{a}$ \\
\cline { 2 - 5 } & Organic $(n=25)$ & $1.01 \pm 0.44 \mathrm{a}$ & $2.31 \pm 0.92 \mathrm{a}$ & $7.56 \pm 2.12 \mathrm{~b}$ \\
\hline Midsummer plant samples & Conventional $(n=17)$ & $1.13 \pm 0.19 \mathrm{a}$ & $2.68 \pm 0.61 \mathrm{a}$ & $5.12 \pm 0.93 \mathrm{a}$ \\
\cline { 2 - 5 } & Organic $(n=25)$ & $1.50 \pm 0.22 \mathrm{~b}$ & $3.60 \pm 0.94 \mathrm{~b}$ & $10.40 \pm 2.20 \mathrm{~b}$ \\
\hline
\end{tabular}

$z$ Letters indicate significant differences among samples based on Welch's $t$ test $(P<0.004)$. Refer to the main text for details on sampling soil and plants from each field, and for calculation of Shannon's index, inverse Simpson's index, and richness. 
communities did not differ much between sampling periods/ sampling methods. This suggests relatively robust AMF communities exist in soils in this semiarid region, where irrigated agricultural production has replaced native sage brush vegetation in the last 5 to 80 years, depending on the specific farm and field location, following development of the Columbia Basin Irrigation District in the 1950s (Columbia Basin Irrigation District 2017). The land in this region has been planted with diverse annual crops (e.g., potato, onion, wheat, pea, corn, carrot, etc.) as well as biennial and perennial crops (e.g., alfalfa, apple, pear, cherry, blueberry, etc.), which may have selected for a few dominant groups within Glomeromycota that are tolerant to the levels of $\mathrm{P}$ in these soils following extended periods of fertilizer applications.

The organic fields surveyed in this study had moderate soil $\mathrm{P}$ levels ( $30 \mathrm{mg}$ of $\mathrm{P} / \mathrm{kg}$ of soil, on average) that were less than those of the conventional fields surveyed (average of $49 \mathrm{mg}$ of $\mathrm{P} / \mathrm{kg}$ of soil). Henrichs et al. (2017) pasteurized soil sampled from a field in the Columbia Basin that had $20 \mathrm{mg}$ of $\mathrm{P} / \mathrm{kg}$, amended the soil to generate samples with 20,40 , and $80 \mathrm{mg}$ of $\mathrm{P} / \mathrm{kg}$ of soil, inoculated the soil with a commercial AMF product, and planted onion seed. Root colonization decreased significantly with increasing soil $\mathrm{P}$ level, from $>40 \%$ in soil with $20 \mathrm{mg}$ of $\mathrm{P} / \mathrm{kg}$ of soil to $<20 \%$ in soil with $\sim 80 \mathrm{mg}$ of $\mathrm{P} / \mathrm{kg}$ of soil. This demonstrated the potential negative effects of greater soil $\mathrm{P}$ levels on AMF colonization of onion roots. We anticipated AMF root colonization would be less in conventional than organic fields, which did not prove true. The relatively high levels of AMF colonization of onion roots in organic and conventional fields in this survey, despite moderate to high levels of soil $\mathrm{P}$, were also contrary to what was reported by Hijri et al. (2006). Hijri found the high levels of soil $P$ after conversion of fields from conventional to organic production inhibited AMF colonization of roots. In a survey of 40 organic onion fields and 38 conventional onion fields in the Netherlands, Galván et al. (2009) found differences in soil $\mathrm{P}$ levels between organic and conventional fields (30 to 32 versus 42 to $45 \mathrm{mg}$ of $\mathrm{P}_{2} \mathrm{O}_{5}$ per liter of soil, respectively), and detected greater AMF colonization of roots in organic than conventional fields in Zeeland but not in Flevoland. Despite relatively high soil $\mathrm{P}$ levels, onion yields were positively correlated with AMF colonization levels of roots in conventional fields.

The other interesting finding from the Columbia Basin onion survey was the dominance of three or four AMF taxa in the roots of onion plants in these fields. Colonization by multiple species may result in a functional redundancy, so that even if one species is eliminated, other species can perform the same association with onion roots. Although these AMF may not give plants a benefit of increased P uptake under the soil P levels detected in these fields, the fungi may serve other beneficial functions such as resistance to water or heat stress, and increased resistance or tolerance to certain diseases and insect pests (Jaime et al. 2008; Sharma-Poudyal et al. 2014; Torres-Barragán et al. 1996).

Conclusions. Glomus and Claroideoglomus were the most abundant taxa detected in onion roots in the Columbia Basin of the Pacific Northwest United States by pyrosequencing. The abundance of the most dominant taxa did not differ between organic and conventional onion cropping systems; however, a number of minor taxa detected in the organic fields were not detected in the conventional fields. There were significant differences in AMF community structure between organic and conventional fields, especially for plants sampled from growers' crops midsummer. Overall, AMF richness and diversity were greater in the organic fields than the conventional fields. Soil fumigation with metam sodium by chemigation in the autumn, prior to planting onion crops the following spring, did not alter AMF community structure but reduced AMF diversity in two of four pairs of fumigated and nonfumigated conventional onion fields surveyed. Overall, the

TABLE 5

Diversity measures of arbuscular mycorrhizal fungi detected in soil sampled in autumn 2014 (prefumigation) and in spring 2015 (postfumigation) from eight onion fields in the Columbia Basin of the Pacific Northwest United States, prior to soil fumigation of half of the fields with metam sodium by chemigation using center pivot irrigation

\begin{tabular}{|c|c|c|c|c|c|}
\hline Soil sampling time & Field $^{x}$ & Pair & Shannon $\left(H^{\prime}\right)$ & Inverse Simpsons (1/D) & Richness (S) \\
\hline \multirow[t]{5}{*}{ Autumn 2014 (prefumigation of the $\mathrm{F}$ fields) } & $\mathrm{NF} 1(n=5)$ & A & $1.07 \pm 0.13 \mathrm{a}^{y}$ & $2.29 \pm 0.32 a$ & $7.40 \pm 1.99 a$ \\
\hline & $\mathrm{F} 1(n=4)$ & $A$ & $0.89 \pm 0.09 b$ & $2.13 \pm 0.30 a$ & $3.25 \pm 0.50 b$ \\
\hline & $\mathrm{F} 2(n=4)$ & $B$ & $1.35 \pm 0.23 \mathrm{a}$ & $3.35 \pm 0.94 a$ & $6.75 \pm 1.50 \mathrm{a}$ \\
\hline & F3 $(n=4)$ & C & $0.89 \pm 0.25 a$ & $2.03 \pm 0.63 a$ & $5.75 \pm 0.96 a$ \\
\hline & $\mathrm{F} 4(n=4)$ & $\mathrm{D}$ & $1.14 \pm 0.06 \mathrm{a}$ & $2.69 \pm 0.26 a$ & $6.25 \pm 0.96 a$ \\
\hline \multirow[t]{5}{*}{ Spring 2015 (postfumigation of the $\mathrm{F}$ fields) } & NF1 $(n=4)$ & $A$ & $0.49 \pm 0.22$ & $1.28 \pm 0.19$ & $7.50 \pm 2.08$ \\
\hline & $\mathrm{F} 1(n=4)$ & $A$ & $-{ }^{z}$ & - & \\
\hline & NF2 $(n=5)$ & $B$ & $1.50 \pm 0.17$ & $3.60 \pm 0.76$ & $8.00 \pm 0.71$ \\
\hline & NF4 $(n=5)$ & $\mathrm{D}$ & $1.02 \pm 0.26$ & $2.18 \pm 0.68$ & $7.20 \pm 1.3$ \\
\hline & $\mathrm{F} 4(n=5)$ & $D$ & $0.98 \pm 0.22$ & $2.28 \pm 0.53$ & $5.80 \pm 0.84$ \\
\hline
\end{tabular}

$\times \mathrm{NF}=$ nonfumigated, $\mathrm{F}=$ fumigated

y Mean \pm standard deviation followed by different letters indicate significant differences in diversity within each field pair (Welch's $t$ test $P<0.05)$. Refer

to the main text for details on sampling soil and plants from each field, and for calculation of Shannon's index, inverse Simpson's index, and richness.

z - Indicates data missing for soil samples collected from field F1 postfumigation (spring 2015). 
results suggest that the dominant $\mathrm{AMF}$ taxa are adapted to moderate to high $\mathrm{P}$ levels present in both organic and conventional onion crops in the Columbia Basin.

\section{ACKNOWLEDGMENTS}

We thank onion growers in the Columbia Basin for their collaboration, and seed companies for providing onion seed.

\section{LITERATURE CITED}

Afek, U., Rinaldelli, E., Menge, J. A., Johnson, E. L. V., and Pond, E. 1990. Mycorrhizal species, root age, and position of mycorrhizal inoculum influence colonization of cotton, onion, and pepper seedlings. J. Am. Soc. Hortic. Sci. 115:938-942.

Anderson, M. J. 2001. A new method for non-parametric multivariate analysis of variance. Austral. Ecol. 26:32-46.

Baoming, J., Gehring, C. A., Wilson, G. W. T., Miller, R. M., Flores-Renteria, L., and Johnson, N. C. 2013. Patterns of diversity and adaptation in Glomeromycota from three prairie grasslands. Mol. Ecol. 22:2573-2587.

Benjamini, Y., and Hochberg, Y. 1995. Controlling the false discovery rate: A practical and powerful approach to multiple testing. J. R. Stat. Soc. Series B Stat. Methodol. 57:289-300.

Berruti, A., Lumini, E., Balestrini, R., and Bianciotto, V. 2016. Arbuscular mycorrhizal fungi as natural biofertilizers: Let's benefit from past successes. Front. Microbiol. 6:1559.

Brewster, J. 2008. Onions and Other Vegetable Alliums. CAB International, Wallingford, UK.

Caporaso, J. G., Kuczynski, J., Stombaugh, J., Bittinger, K., Bushman, F. D., and Costello, E. 2010. QIIME allows analysis of high-throughput community sequencing data. Nat. Methods 7:335-336.

Charron, G., Furlan, V., Bernier-Cardou, M., and Doyon, G. 2001a. Response of onion plants to arbuscular mycorrhizae 1. Effects of inoculation method and phosphorus fertilization on biomass and bulb firmness. Mycorrhiza 11: 187-197.

Charron, G., Furlan, V., Bernier-Cardou, M., and Doyon, G. 2001b. Response of onion plants to arbuscular mycorrhizae 2. Effects of nitrogen fertilization on biomass and bulb firmness. Mycorrhiza 11:145-150.

Cheng, X. M., and Baumgartner, K. 2004. Survey of arbuscular mycorrhizal fungal communities in Northern California vineyards and mycorrhizal colonization potential of grapevine nursery stock. HortScience 39:1702-1706.

Clarke, K. R. 1993. Non-parametric multivariate analyses of changes in community structure. Austral. Ecol. 18:117-143.

Clarke, R. K., Somerfield, P. J., and Chapman, M. G. 2006. On resemblance measures for ecological studies, including taxonomic dissimilarities and a zero-adjusted Bray-Curtis coefficient for denuded assemblages. J. Exp. Mar. Biol. Ecol. 330:55-80.

Columbia Basin Irrigation District. 2017. http://columbiairrigation.com/aboutcid/history/ (accessed November 2017)

Daniell, T. J., Husband, R., Fitter, A. H., and Young, J. P. W. 2001. Molecular diversity of arbuscular mycorrhizal fungi colonising arable crops. FEMS Microbiol. Ecol. 36:203-209.

Davison, J., Opik, M., Zobel, M., Vasar, M., Metsis, M., and Moora, M. 2012. Communities of arbuscular mycorrhizal fungi detected in forest soil are spatially heterogeneous but do not vary throughout the growing season. PLoS One 7:e41938.

Dowd, S. E., Callaway, T. R., Wolcott, R. D., Sun, Y., McKeehan, T., and Hagevoort, R. G. 2008a. Evaluation of the bacterial diversity in the feces of cattle using 16S rDNA bacterial tag-encoded FLX amplicon pyrosequencing (bTEFAP). BMC Microbiol. 8:125.

Dowd, S. E., Sun, Y., Wolcott, R. D., Domingo, A., and Carroll, J. A. 2008b. Bacterial tag-encoded FLX amplicon pyrosequencing (bTEFAP) for microbiome studies: Bacterial diversity in the ileum of newly weaned Salmonella-infected pigs. Foodborne Pathog. Dis. 5:459-472.

du Toit, L. J., Paulitz, T., Sharma-Poudyal, D., and Knerr, A. J. 2014. Impact of arbuscular mycorrhizal fungi on $\mathrm{P}$ use efficiency and root diseases of onion crops in the Columbia Basin. Washington State University Center for Sustaining Agriculture \& Natural Resources BIOAg Project Report. http:// csanr.wsu.edu/grants/impact-of-arbuscular-mycorrhizal-fungi-onphosphorus-use-efficiency-and-root-diseases-of-onion-crops/

Dumbrell, A. J., Nelson, M., Helgason, T., Dytham, C., and Fitter, A. H. 2010. Idiosyncrasy and overdominance in the structure of natural communities of arbuscular mycorrhizal fungi: Is there a role for stochastic processes? J. Ecol. 98:419-428.

Fester, T., and Sawers, R. 2011. Progress and challenges in agricultural applications of arbuscular mycorrhizal fungi. CRC Cr Rev Plant Sci 30: 459-470.

Finlay, R. D. 2004. Mycorrhizal fungi and their multifunctional roles. Mycologist 18:91-96

Galván, G. A., Parádi, I., Burger, K., Baar, J., Kuyper, T. W., Scholten, O. E., and Kik, C. 2009. Molecular diversity of arbuscular mycorrhizal fungi in onion roots from organic and conventional farming systems in the Netherlands. Mycorrhiza 19:317-328.

Giovannetti, M., and Mosse, B. 1980. An evaluation of techniques for measuring vesicular arbuscular mycorrhizal infections in roots. New Phytol. 84:489-500.

Gorzelak, M. A., Holland, T. C., Xing, X. K., and Hart, M. M. 2012. Molecular approaches for AM fungal community ecology: A primer. J. Microbiol. Methods 90:108-114.

Gosling, P., Ozaki, A., Jones, J., Turner, M., Rayns, F., and Bending, G. D. 2010. Organic management of tilled agricultural soils results in a rapid increase in colonisation potential and spore populations of arbuscular mycorrhizal fungi. Agric. Ecosyst. Environ. 139:273-279.

Helgason, T., and Fitter, A. 2005. The ecology and evolution of the arbuscular mycorrhizal fungi. Mycologist 19:96-101.

Henrichs, B., Waters, T. D., and du Toit, L. J. 2017. The effect of soil phosphorus levels on colonization of onion roots by arbuscular mycorrhizal fungi, 20162017. Plant Dis. Manage. Rep. 11:V125.

Hewitt, E. 1966. Sand and water culture methods used in the study of plant nutrition. Rev. 2nd ed., Technical Communication (Commonwealth Bureau of Horticulture and Plantation Crops). No. 22. Farnham Royal, Commonwealth Agricultural Bureaux.

Hijri, I., Zuzana, S., Korova, Y., Oehl, F., Ineichen, K., Mader, P., Wiemken, A., and Redecker, D. 2006. Communities of arbuscular mycorrhizal fungi in arable soils are not necessarily low in diversity. Mol. Ecol. 15:2277-2289.

House, G. L., Ekanayake, S., Ruan, Y., Schütte, U. M. E., Kaonongbua, W., Fox, G., Ye, Y., and Bever, J. D. 2016. Phylogenetically structured differences in rRNA gene sequence variation among species of arbuscular mycorrhizal fungi and their implications for sequence clustering. Appl. Environ. Microbiol. 82:4921-4930.

Jaime, M. D. L. A., Hsiang, T., and McDonald, M. R. 2008. Effects of Glomus intraradices and onion cultivar on Allium white rot development in organic soils in Ontario. Can. J. Plant Pathol. 30:543-553.

Jansa, J., Mozafar, A., Kuhn, G., Anken, T., Ruh, R., Sanders, I. R., and Frossard, E. 2003. Soil tillage affects the community structure of mycorrhizal fungi in maize roots. Ecol. Appl. 13:1164-1176.

Knerr, A. J., Wheeler, D., Schlatter, D., Paulitz, T., and du Toit, L. J. 2016. Arbuscular mycorrhizal fungal communities associated with organic and conventional onion crops in the Columbia Basin of Washington. (Abstr.) Phytopathology 106(suppl.):):S4.35.

Kumar, S., Stecher, G., and Tamura, K. 2015. MEGA7: Molecular evolutionary genetics analysis version 7.0 for bigger datasets. Mol. Biol. Evol. 33: 1870-1874.

Ludwig-Muller, J., Bennett, R. N., Garcia-Garrido, J. M., Piche, Y., and Vierheilig, H. 2002. Reduced arbuscular mycorrhizal root colonization in Tropaeolum majus and Carica papaya after jasmonic acid application cannot be attributed to increased glucosinolate levels. J. Plant Physiol. 159:517-523.

Makus, D. J. 2002. Mycorrhizal inoculation of tomato and onion transplants improves earliness. XXVI Internat. Hortic. Congress: Issues Adv. Transplant Prod. Stand. Establ. Res. 631:275-281.

Martinez, T. N., and Johnson, N. C. 2010. Agricultural management influences propagule densities and functioning of arbuscular mycorrhizas in low- and high-input agroecosystems in arid environments. Appl. Soil Ecol. 46: 300-306.

Morris, E. K., Caruso, T., Buscot, F., Fischer, M., Hancock, C., Maier, T. S., Meiners, T., Müller, C., Obermaier, E., and Prati, D. 2014. Choosing and using diversity indices: Insights for ecological applications from the German Biodiversity Exploratories. Ecol. Evol. 4:3514-3524.

Opik, M., Moora, M., Zobel, M., Saks, U., Wheatley, R., Wright, F., and Daniell, T. 2008. High diversity of arbuscular mycorrhizal fungi in a boreal herb-rich coniferous forest. New Phytol. 179:867-876.

Opik, M., Vanatoa, A., Vanatoa, E., Moora, M., Davison, J., and Kalwij, J. M. 2010. The online database MaarjAM reveals global and ecosystemic distribution patterns in arbuscular mycorrhizal fungi (Glomeromycota). New Phytol. 188:223-241.

Pellerin, S., Mollier, A., Morel, C., and Plenchette, C. 2007. Effect of incorporation of Brassica napus L. residues in soils on mycorrhizal fungus 
colonisation of roots and phosphorus uptake by maize (Zea mays L.). Eur. J. Agron. 26:113-120.

Pelter, G. Q., and Sorensen, E. 2003. Crop profile for onions in Washington. Technical report. Regional Integrated Pest Management Centers, USDA. https://ipmdata.ipmcenters.org/source_report.cfm? sectionid $=40 \&$ sourceid $=544$

Rognes, T., Flouri, T., Nichols, B., Quince, C., and Mahé, F. 2016. VSEARCH: A versatile open source tool for metagenomics. PeerJ 4:e2584.

Rosendahl, S., and Stukenbrock, E. H. 2004. Community structure of arbuscular mycorrhizal fungi in undisturbed vegetation revealed by analyses of LSU rDNA sequences. Mol. Ecol. 13:3179-3186.

Schloss, P. D., Westcott, S. L., Ryabin, T., Hall, J. R., Hartmann, M., and Hollister, E. B. 2009. Introducing mothur: Open-source, platformindependent, community-supported software for describing and comparing microbial communities. Appl. Environ. Microbiol. 75:7537-7541.

Schreiner, R. P., and Koide, R. T. 1993a. Antifungal compounds from the roots of mycotrophic and non-mycotrophic plant species. New Phytol. 123: 99-105.

Schreiner, R. P., and Koide, R. T. 1993b. Mustards, mustard oils and mycorrhizas. New Phytol. 123:107-113.

Shannon, C. E. 1975. The Mathematical Theory of Communication. University Illinois Press, Urbana.

Sharma, M. P., Gaur, A., Tanu, U., and Sharma, O. P. 2004. Prospects of arbuscular mycorrhiza in sustainable management of root- and soil-borne diseases of vegetable crops. Pages 501-539 in: Disease Management of Fruits and Vegetables. Vol. 1. Fruit and Vegetable Diseases. Kluwer Academic Publishers, Netherlands.

Sharma-Poudyal, D., Paulitz, T. C., Linderman, R. G., and du Toit, L. J. 2014. Effect of arbuscular mycorrhizal fungi on onion growth and onion stunting caused by Rhizoctonia solani, 2013. Plant Dis. Manage. Rep. 8:V305.

Simpson, E. H. 1949. Measurement of diversity. Nature 163:688.

Smith, E., and Smith, F. A. 2011. Roles of arbuscular mycorrhizas in plant nutrition and growth: New paradigms from cellular to ecosystem scales. Annu. Rev. Plant Biol. 62:227-250.

Torres-Barragán, A., Zavaleta-Mejía, E., González-Chávez, C., and FerreraCerrato, R. 1996. The use of arbuscular mycorrhizae to control onion white rot (Sclerotium cepivorum Berk.) under field conditions. Mycorrhiza 6:253-257.

United States Department of Agriculture National Agricultural Statistics Service. 2017. https://www.nass.usda.gov/Data_and_Statistics/index.php

Van Geel, M., Busschaert, P., Honnay, O., and Lievens, B. 2014. Evaluation of six primer pairs targeting the nuclear rRNA operon for characterization of arbuscular mycorrhizal fungal (AMF) communities using 454 pyrosequencing. J. Microbiol. Methods 106:93-100.

Verheilig, H., Coughlan, A. P., Wyss, U., and Piché, Y. 1998. Ink and vinegar, a simple staining technique for arbuscular-mycorrhizal fungi. Appl. Environ. Microbiol. 64:5004-5007.

Weil, R. R., and Brady, N. C. 2017. The Nature and Properties of Soil, 15th ed. Pearson, Boston, MA. 